\title{
DOUGLAS W. KIRKLAND: ROLE OF HYDROGEN SULFIDE IN THE FORMATION OF CAVE AND KARST PHENOMENA IN THE GUADALUPE MOUNTAINS AND WESTERN DELAWARE BASIN, NEW MEXICO AND TEXAS
}

National Cave and Karst Research Institute. Special Paper 2, (2 un-numbered pages) + vii + 77pp., National Cave and Karst Research Institute, Carlsbad NM, 2014.

In the Foreword to this A4format paperback book the Managing Editor, Lewis Land, notes that, “... this publication will serve as an important source book and milestone for future research in the Delaware Basin region for many years to come." The present reviewer is of the opinion that the book is much more. As with the first edition of the NCKRI Special Paper (Alexander Klimchouk: Hypogene Speleogenesis: Hydrogelogical and Morphogenetic Perspective.), the current one presents a milestone in the general development of ideas related to speleogenesis. If twentiethcentury karst science examined the karst from three slightly different viewpoints, i.e. karst hydrogeology, speleology and karst geomorphology, Kirkland's present work introduces novel aspects, which return to the basics of general sedimentology and (bio)geochemistry in a broad sense The actual state of the karst underground in the studied area is not merely a "karstified (whatever that expression might mean) rocky mass" but an obvious stage in the diagenesis of the carbonate-sulphate-halite body that, during geological time, has been exposed to

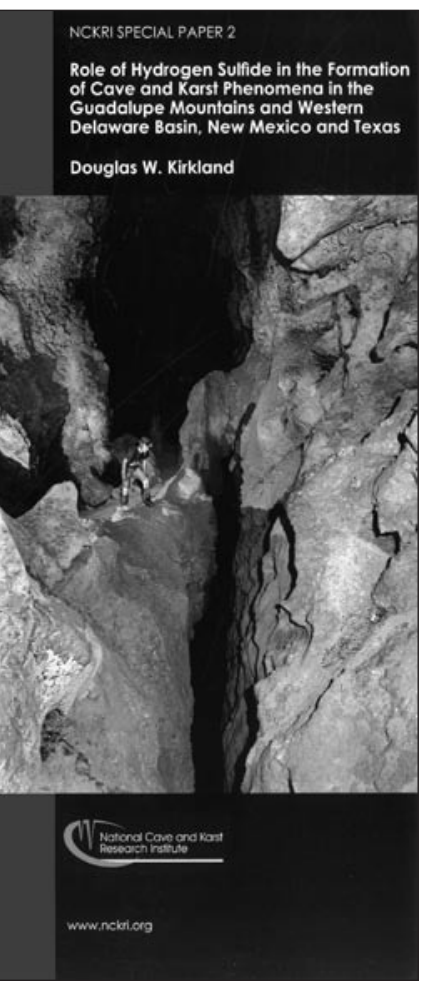

both hypogene and epigene water. Individual caves are scarcely mentioned - the focus remains upon development in the "Cave Belt" as a whole and its geoenvironment.

Kirkland's work is the dénouement of almost 20 years of research in southeastern New Mexico and western Texas, at the same time summarizing, discussing and incorporating decades of research by previous workers combined with his new ideas. Though sulfide speleogenesis remains the central point of concern, development of the parent rocks (from sedimentation up until the present), including local tectonic effects, had to be broadly considered. From this point of view the book presents an example of how different branches of the earth sciences should be involved in physical karst science studies in the future. The study was made more challenging by the area's unusual geological history, particularly the complex history of diagenesis; undoubtedly those with a grounding in modern oil geology will find the text easier to understand. 
The book's contents are arranged into three sections, covering the main foci of the research. Its scientific core is preceded by, Foreword, Contents List of Figures (63 in total), and Abstract. At the end are Summary and Conclusions, Acknowledgments, and References Cited (228 in total). Chapters and sections are not numbered. The main section titles speak for themselves: Introduction (Objectives and Purpose of the investigation), Sulfidic Origin of Caves of the Guadalupe Mountains, Origin of Major Deposits of Native Sulfur, and Methane as Microbial Foodstuff.

Further, the sections are split into chapters, and the main one (Sulfidic Origin ...) also into sub-chapters. Its chapters and sub-chapters (shown in brackets below) are as follows: Geographic and Stratigraphic Setting of Caves, Peculiar Qualities and Unusual Origin of Caves, Role of Sulfuric Acid in Cave Formation, Attributes of Hydrogen Sulfide Transported to the Caves (Curious Sulfur Isotopic Composition, Microbial Derivation, Immense Quantity), Sources and Pathways of Hydrogen Sulfide: Previous Models (The Existing Shelfal Model, The Existing Basinal Model, Modified Basinal Model: Source of Hydrogen Sulfide and its Pathway to Caves (Beginning of Intense Cavern Formation, Formation of Basinal Hydrologic Pathways, Generation and Migration of Methane in Late Tertiary of Western Delaware Basin, Reaction between Methane and Sulfate Anions in Late-Tertiary of Western Delaware Basin, Transit of Hydrogen SulfideCharged Water through Conduits within Castile Halite into Capitan Formation, Progressive Oxidation of Hydrogen Sulfide from Southwest to Northeast along the Cave Belt and from Higher to Lower Elevations within Individual Caves), Dissolution of Castile and Salado Halite and Gypsum by Epigenic Groundwater. (Sub-subchapters, if they exist, are omitted from this list.)

The text is clear though very compact. Statements are concise and well founded, based either upon the author's original findings, or upon extensive, partly quite specialized, literature. Figures (mostly drawings) are clear, without irrelevant padding. A parallel product of the paper is the introduction of some less widely known geomorphic terms, such as castile, which have become important in discussions of evaporite karst.

The complexity of the central issue and the main ideas may be exposed by a few citations from the Summary. "An immense weight (millions of metric tons) of microbial hydrogen sulfide $\left(\mathrm{H}_{2} \mathrm{~S}\right)$ moved into caves of the Guadalupe Mountains during the late Miocene and early Pliocene ( 12-4 million years ago). The $\mathrm{H}_{2} \mathrm{~S}$ reacted with $\mathrm{O}_{2}$ chiefly within subaerial water of condensation to form sulfuric acid $\left(\mathrm{H}_{2} \mathrm{SO}_{4}\right)$ - the primary cave-forming agent ... The caves formed within ... reefal limestone ... and within adjacent, time-equivalent, shelfal carbonates
...” (p.61); “... the $H_{2} S$ involved in speleogenesis was probably transported into the evolving caves from the adjoining Delaware Basin through upwardinclined pathways within Castile halite ..." (pp. 61); "Two approximately coeval Late Tertiary events superimposed on the consistent Castile stratigraphic framework resulted in intense $\mathrm{H}_{2} \mathrm{~S}-\mathrm{H}_{2} \mathrm{SO}_{4}$ speleogenesis in the Guadalupe Mountains. These events were - high-heat flow, ..., and - eastward tilting of the paleo-Guadalupe tectonic block, ..." (pp. 61); "The free convective process resulted in chambers being dissolved vertically upward within the Halite I Member until they contacted the intact base of the next overlying bed of anhydrite ..., which dipped uniformly eastward over thousands of square kilometers. Then, by the same process of convective dissolution, but in an abrupt change in dip (from $\sim 90^{\circ}$ to $<\sim 1^{\circ}$ ) and in direction of dip (from upward to westward), anhydrite-capped voids advanced up the slight homoclinal slope for up to several tens of kilometers. The solvent, nearly saturated with $\mathrm{CaSO}_{4}$, no longer readily dissolved anhydrite. The conduits, ..., were confined to halite. The width of dissolution conduits is inferred to have been narrow $(<\sim 30 \mathrm{~m})$; their height, low $(<\sim 2 \mathrm{~m}$ ); and their length, long (up to tens of kilometers)." (pp. 61-62); "Halite dissolved most actively ... where solutionally aggressive groundwater directly contacted halite. Here, the convectively flowing groundwater abruptly and diametrically changed direction. Just beneath rising aggressive water (in a two-way stream), brine saturated with $\mathrm{NaCl}$ flowed easterly within conduits directly down the slight slope of the homocline, and passed through fractures, breccias, and voids within the Anhydrite I Member and drained into sandstone of the Bell Canyon Formation. Growing conduits continuously advanced westerly up the homoclinal slope as the ascending, aggressive groundwater dissolved halite. Many conduits eventually contacted the steep face of the reef or the steep face of the forereef; here Castile halite was flush against Capitan carbonates." (pp. 62); "The "cave belt" of the Guadalupe Mountains, a six-kilometer-wide band parallel to and including the Capitan reef, has a northeast-southwest trend across the uniformly eastward dipping, Guadalupe tectonic block. Because of this configuration, on uplift of the homoclinal tectonic block the highest elevation of the cave belt was to the southwest. Erosion, which generally progressed down the tectonic block from west to east, probably initially removed the stratal cover ... from the most elevated southwestern part of the cave belt. In step with intermittent uplifts, erosional removal of the evaporitic cover from the cave belt probably progressed to the southeast over millions of years." (pp. 62); "A primary control over both $\mathrm{H}_{2} \mathrm{~S}-\mathrm{H}_{2} \mathrm{SO}_{4}$ speleogenesis in the Guadalupe Mountains and $\mathrm{H}_{2} \mathrm{~S}-\mathrm{S}$ genesis in the Delaware Basin was availability of $\mathrm{O}_{2}$. Abundant $\mathrm{H}_{2} \mathrm{~S}$... charged the sluggishly moving 
groundwater in the lower part of the ancestral Capitan aquifer, which over much of its extent coincided (in plan) with the cave belt. $\mathrm{O}_{2}$ was dissolved within groundwater in the upper part of the aquifer in meager concentrations, and generation of minor quantities of aqueous $\mathrm{H}_{2} \mathrm{SO}_{4}$ at a pycnocline may have resulted in incipient caves. Intense speleogenesis began only when atmospheric $\mathrm{O}_{2}$ became available to these initially formed caves." (pp. 62); ".. during an interval of $\sim 8 \mathrm{Ma}$ - with additional episodes of uplift, descent of the water table, and erosion of the coverspeleogenesis descended progressively in steps both within the slightly inclined $\left(<0.5^{\circ}\right)$ northeast-trending cave belt and within individual caves." (pp. 62); "A genetic and geographic relationship exists between caves of the Guadalupe Mountains and large deposits of native sulfur ... beneath the adjacent Gypsum Plain. The deposits and the caves probably formed at about the same time, and they probably both owe their existence to a coincidence of essentially the same stratigraphic, thermal, biogenic, and tectonic events." (pp. 62+).
Kirkland's work has shed a quite new light upon the understanding of speleogenesis in general and is an essential "must read" for every serious, $21^{\text {st }}$ century, karstologist. The present reviewer presumes that the (listed) peer reviewers would share this opinion.

The book is distributed by the National Cave and Karst Research Institute, 400-1 Cascades Ave., Carlsbad, NM 88220, USA; www.nckri.org. The file can be downloaded at http://nckri.org/about_nckri/nckri_publications.htm. 